\title{
PENINGKATAN KREATIVITAS SENI DALAM DESAIN BUSANA
}

\section{Nanie Asri Yuliati}

\section{Pendidikan Teknik Busana FT Universitas Negeri Yogyakarta}

\section{Abstract}

Creativity in cloth designing is one of aspects to improve fashion products. The products in garment industry include many kinds of clothes in the markets, such as women's, men's, children's and adults' clothes for many occasions like parties' and work's clothes. To compete in the markets, fashion designers have to be creative in designing the clothes. Creativity is new ideas in designing to to be creative in designing the clothes. Creativity is new ideas
create novel designs and products suitable with the current trends.

To trigger creativity in the learning of fashion design, the role of learning sources is important so that the students get inspired by the novelties to create new fashion.

The learning sources include electronic media (TV, video and the internet), printed media (fashion books and magazines, tabloids, and newspapers) as well as direct sources observed in daily life. Varied learning sources will improve creativity in fashion design learning.

Key words: learning sources, creativity, cloth design

\section{A. Pendahuluan}

Keberhasilan seseorang yang sedang belajar selalu dianggap bergantung pada orang yang belajar. Namun, kenyataannya banyak hal yang mempengaruhi keberhasilan tersebut, di antaranya faktor siswa, guru, proses belajar-mengajar, lingkungan belajar, dan media pembelajaran.

Guru merupakan medium aktif yang sangat besar pengaruhnya untuk mencapai keberhasilan pengajaran. Tugas guru menciptakan suasana di dalam kelas, sehingga terjadi interaksi belajar-mengajar yang dapat mendorong siswa belajar dengan baik. Adapun keterampilan mengajar yang efektif, efisien, dan relevan dengan tujuan pendidikan tertuang dalam kompentensi guru, di antaranya guru harus dapat memilih media (sumber belajar) dengan tepat. Masing-masing guru mempunyai cara yang berbeda untuk mencapai keberhasilan belajarmengajar, apalagi setiap pelajaran/mata kuliah mempunyai ciri atau karakter yang berbeda. Oleh karena itu, diharapkan guru berusaha menyiapkan srategi yang berbeda untuk masing masing mata pelajaran dalam usaha mencapai tujuan pembelajaran yang telah ditetapkan.

Pada saat ini terdapat beberapa tantangan yang kelak akan menentukan masa depan bangsa dan negara Indonesia, khususnya dalam dunia usaha. Sejak 2003 telah ditetapkan Asean Free Trade Area (AFTA). Pada era ini lalu lintas barang dan jasa tidak lagi mengenal batas-batas negara. Bahkan, persaingan tenaga kerja pun semakin ketat dan kompetitif. Permasalahan yang dihadapi oleh setiap 
negara pada era perdagangan bebas adalah persaingan mutu dari sumber daya manusia (SDM) yang meliputi aspek kemampuan berpikir, kemampuan psikomotorik, dan kemampuan bekerja (Mardapi, 1995: 1).

Era globalisasi menuntut penyedia SDM, salah satunya adalah perguruan tinggi, untuk merencanakan proses pembelajaran siswa atau mahasiswa sesuai dengan kebutuhan lapangan kerja yang dituntut mempunyai kemampuan dan kreativitas tinggi.

Demikian juga, perguruan tinggi yang menyiapkan SDM yang akan berusaha atau bekerja di bidang busana sangatlah penting dalam peningkatan kreativitas, terutama dalam hal desain busana. Mata pelajaran desain busana menuntut kreativitas tinggi dalam membuat desain busana, sedangkan mode busana berkembang setiap saat dan harus selalu mengikuti tren yang ada.

Produk busana dalam arti luas meliputi berbagai busana pria, wanita, anak, dewasa yang dipakai di berbagai kesempatan yang berbeda, seperti pesta, kerja, dan lain-lain. Adapun proses pembuatan desain busana diawali dengan melihat kebutuhan pasar, selanjutnya dilakukan penjajagan terhadap mode dan tren yang sedang digemari masyarakat, membuat kreasi baru, dan membuat pengembangan desain.

Proses pembuatan desain busana yang selalu berkembang memerlukan sumber-sumber belajar sebagai sumber inspirasi dalam meningkatkan kreativitas pembuatan desain busana. Sumber belajar sangatlah penting sebagai sumber imajinasi seorang perancang busana atau seseorang yang sedang belajar membuat desain busana.

\section{B. Pembahasan}

1. Sumber Belajar

Belajar adalah kegiatan yang menghasilkan perubahan tingkah laku pada diri individu yang sedang belajar, baik potensi maupun aktual. Perubahan tersebut dalam bentuk kemampuan atau pengetahuan baru yang dimiliki setelah megalami proses belajar-mengajar. Proses belajar-mengajar merupakan suatu sistem yang tidak dapat lepas dari komponenkomponen lain yang saling terkait di dalamnya, salah satunya adalah sumber belajar.

Guru merupakan sumber belajar personal, sedangkan media merupakan sumber belajar nonpersonal. Keduanya dianjurkan untuk saling melengkapi aga kegiatan belajar-mengajar tidak membosankan serta dapat merangsang keaktifan, minat, dan kreativitas siswa.

Menurut Winkel (1996: 258) media pembelajaran atau yang disebut sumber belajar adalah sarana nonpersonal yang digunakan atau disediakan oleh tenaga pengajar untuk mencapai tujuan. Sujana \& R.Ibrahim (1996: 12) mengatakan bahwa pengertian media pembelajaran (sumber belajar) adalah segala sesuatu yang dapat digunakan untuk menyalurkan pesan atau isi pelajaran, merangsang pikiran atau perasaan, perhatian, dan kemampuan siswa, sehingga dapat mendorong proses belajar-mengajar. Sedang menurut Hamalik (1994: 23) mendefinisikan media pendidikan sebagai alat, metode, dan teknik yang digunakan untuk lebih mengefektifkan komunikasi dan interaksi antara guru dan siswa dalam proses pendidikan dan pengajaran di sekolah.

Menurut Beswick (1977) pembelajaran berdasarkan sumber-sumber "Resource based learning" melibatkan keikutsertaan secara aktif atas berbagai sumber belajar (buku, jurnal, surat kabar, multi media, web, masyarakat, orangorang), yang dengan itu para siswa akan termotivasi untuk belajar dengan berusaha menemukan informasi sebanyak mungkin.

Dari beberapa pendapat tersebut di atas dapat disimpulkan bahwa media pembelajaran merupakan sumber belajar nonpersonal yang digunakan atau disediakan oleh guru untuk membantu mentransfer materi pelajaran yang dapat merangsang pikiran, perasaan, dan kemampuan siswa, sehingga lebih mengefektifkan komunikasi dan interaksi belajar-mengajar dalam rangka mencapai tujuan pembelajaran.

Guru bukan satu-satunya sumber belajar. Tidak ada satu sumber belajar pun yang paling cocok dan paling tepat digunakan dalam proses belajarmengajar. Setiap sumber belajar mempunyai kelebihan dan kekurangan, bergantung pada keperluan penggunaannya. Yang harus diperhatikan dalam penggunaan sumber belajar adalah bagaimana sumber belajar digunakan sesuai dengan tujuan yang akan dicapai, sehingga dapat menarik, menggugah minat siswa dalam meningkatan motivasi belajar. Sujana (1997: 80) mengklasifikasi sumber belajar sebagai berikut.

1) Sumber belajar tercetak: buku-buku, brosur, koran, poster, denah, ensiklopedi, kamus, booklet.

2) Sumber belajar noncetak: slide, film, video, model, audio cassette, transparansi, objek.

3) Sumber belajar yang berbentuk fasilitas: perpustakaan, ruangan belajar, studio, lapangan, laboratorium.

4) Sumber belajar berupa kegiatan: wawancara, kerja kelompok, observasi, simulasi, permainan.

5) Sumber belajar berupa lingkungan masyarakat: taman, terminal, pasar, toko, pabrik, museum.

Demikian halnya, klasifikasi sumber belajar menurut Usman (1993: 94) sebagai berikut.

1) Multi media audio visual dapat digunakan secara efektif dan bervariasi dalam pengajaran.

2) Manusia sebagai sumber belajar: guru, tutor, pejabat, petani, nelayan. 
3) Lingkungan sebagai sumber belajar: gedung sekolah, halaman, laboratorium, perpustakaan, museum, kawasan industri, pertanian, peternakan.

Menurut Nasution (2003: 26) ciri-ciri belajar berdasarkan sumber adalah:

1) Memanfaatkan sepenuhnya segala sumber informasi. Memberi kesempatan untuk merencanakan kegiatan belajar dengan mempertimbangkan sumbersumber yang tersedia.

2) Berusaha memberikan pengertian kepada murid tentang luas dan aneka ragam sumber-sumber informasi yang dapat dimanfaatkan. Sumber-sumber itu berupa sumber dari masyarakat dan lingkungan manusia, museum, organisasi, bahan cetakan, perpustakaan, alat audio-visual, dan seterusnya. Kepada siswa harus diajarkan teknik melakukan kerja lapangan, menggunakan perpustakaan, buku referensi, sehingga mereka lebih percaya diri dalam belajar.

3) Berhasrat untuk mengganti pasivitas murid dalam belajar.

4) Untuk meningkatkan motivasi belajar dengan menyajikan berbagai kemungkinan bahan pelajaran, motode kerja, medium komunikasi.

5) Memberikan kesempatan kepada murid untuk bekerja menurut kecepatan dan kesanggupan masing-masing.

6) Lebih fleksibel dalam penggunaan waktu dan ruang belajar.

7) Berusaha mengembangkan kepercayaan atas diri siswa.

\section{Hakikat Kreativitas}

Istilah kreativitas biasanya diartikan sebagai kemampuan untuk menciptakan produk baru yang unsur-unsurnya sudah ada sebelumnya Kreativitas adalah istilah global yang sulit didefinisikan secara tepat, namun para ahli psikologi berusaha untuk memberikan definisi kreativitas. Kreativitas dimiliki oleh setiap orang meskipun tingkatannya berbeda beda.

Kreativitas adalah daya cipta yang memungkinkan penemuan-penemuan baru dalam bidang ilmu dan teknologi, serta dalam semua bidang usaha manusia (Munandar, 1999: 6). Sedangkan Supriadi (1994: 7) mendefinisikan kreativitas sebagai kemampuan seseorang untuk melahirkan sesuatu yang baru, berupa gagasan maupun karya nyata yang relatif berbeda dengan apa yang telah ada sebelumnya.

Berdasarkan pendapat di atas dapat diambil kesimpulan bahwa kreativitas merupakan kemampuan untuk melahirkan sesuatu yang baru berdasarkan data, informasi, atau unsur-unsur yang ada, berupa gagasan maupun karya nyata dan cara memecahkan masalah yang relatif berbeda dengan apa yang telah ada sebelumnya. Kreativitas merupakan proses yang memberikan peluang bagi individu untuk berpikir dan berusaha mencari jawaban, menemukan metode atau cara baru dan gagasan baru untuk memecahkan masalah.

Ciri-ciri kreativitas menurut Amien (1980: 6) adalah:
1) Fluency (kelancaran) adalah kemampuan seseorang untuk mengemukakan gagasan serupa untuk memecahkan masalah atau seseorang untuk menciptakan ide-ide.

2) Flexibility (keluwesan) adalah kemampuan seseorang untuk menemukan atau menghasilkan berbagai macam ide untuk memecahkan masalah di luar katagori yang biasa. Orang yang kreatif akan memiliki kecenderungan yang sangat mudah untuk menyesuaikan diri dalam pendekatan terhadap suatu masalah. Bila pendekatan yang satu tidak menghasilkan sesuatu yang diharapkan, maka akan segera diadakan pendekatan baru dari sudut yang berbeda.

3) Originality (keaslian) adalah suatu kemampuan memberikan respon yang unik dan luar biasa. Orang yang kreatif biasanya bukan saja dapat menciptakan sejumlah pilihan alternatif, tetapi dapat pula menciptakan ide yang baru. Sebuah ide akan menjadi kreatif apabila pertama-tama bersifat orisinal, setidaknya bagi yang menciptakan atau pada keadaan/tempat/kondisi tersebut dilaksanakan. Orisinalitas merupakan titik penting bagi suatu kreativitas.

4) Elaboraty (kerincian) adalah kemampuan menyatakan ide-ide secara rinci untuk mewujudkannya menjadi kenyataan.

5) Sensitivity (kepekaan) adalah kemampuan untuk mengetahui dengan cepat adanya suatu masalah atau kemampuan untuk melihat adanya suatu kebutuhan.

Berpikir kreatif lebih lengkap apabila diikuti sikap kreatif seseorang, yang meliputi rasa ingin tahu, imajinatif, merasa tertantang oleh kemajemukan, berani mengambil resiko, dan menghargai ide orang lain (Munandar, 1987: 91). Kreativitas merupakan salah satu potensi siswa yang harus dikembangkan agar siswa dapat menerapkan kemampuannya dalam menghadapi dunia kerja yang semakin ketat

Diperlukan usaha untuk meningkatkan kreativitas. Salah satu usaha untuk meningkatkan kreativitas adalah penggunaan media pembelajaran yang lebih bervariasi, sehingga dapat meningkatkan motivasi belajar siswa serta membuat proses belajar-mengajar lebih menarik dan menyenangkan. Upaya peningkatan kreativitas siswa memerlukan dorongan dan dukungan dari lingkungan (motivasi eksternal) yang berupa apresiasi, dukungan, pemberian penghargaan, pujian, insentif, dan lainnya, dan dorongan kuat dari dalam diri siswa itu sendiri (motivasi internal) untuk menghasilkan sesuatu (Munandar, 1999: 68).

\section{Pengertian Desain Busana}

Pengertian desain menurut Chodijah dan Mamdy (1982) adalah suatu susunan dari garis, bentuk, warna, dan tekstur. Menurut Ariyanto (2003: 28) desain adalah elemen desain busana secara lengkap yang terdiri atas garis arah, bentuk, ukuran, warna, nilai, dan tekstur. Menurut Sawitri (1994: 18) desain adalah 
gabungan unsur-unsur garis, bentuk, warna, dan ukuran yang disusun menurut prinsip-prinsip desain dan menghasilkan benda atau karya yang indah dan menarik. Sedangkan menurut Widarwati (1993: 2) desain adalah suatu rancangan atau gambaran objek suatu benda yang dibuat berdasarkan susunan garis, bentuk, warna, dan tekstur. Berdasarkan pengertian tersebut, desain adalah suatu rancangan yang disusun berdasarkan garis, bentuk, warna, ukuran, dan tekstur menjadi satu kesatuan, sehingga menghasilkan sesuatu yang indah dan menarik. meliputi:

Pembuatan desain mencakup unsur-unsur dan prinsip-prinsip yang

1) Garis dan arah; garis adalah kumpulan titik yang mempunyai tujuan dan arah untuk mengungkapkan emosi, perasaan, dan ekspresi.

2) Bentuk; bentuk dibedakan menjadi dua, yaitu: (a) bentuk geometris, seperti segi tiga, segi empat, kerucut, lingkaran, trapesium, dan silinder; (b) bentuk bebas, seperti bentuk daun, bunga, dan titik air. Bentuk-bentuk pada busana dapat berupa bentuk lengan, krah, garis leher, motif, bentuk rok, dan saku.

3) Ukuran; ukuran menentukan panjang pendeknya garis dan besar-kecilnya bentuk menjadi berbeda. Ukuran pada busana digunakan untuk menentukan panjang rok, yaitu rok mini, kini, midi, maxi, dan long dress.

4) Nilai gelap terang; nilai ini menunjukkan apakah warna mengandung hitam atau putih. Nilai ini menunjukkan terang gelapnya corak warna yang digunakan dalam busana. Busana pesta misalnya, pada umumnya menggunakan warna gelap atau warna mencolok (ngejreng).

5) Warna; pemilihan warna yang tidak tepat akan tampak tidak serasi. Kombinasi warna yang tepat akan memberikan kesan indah dan menarik. Untuk busana pesta misalnya, agar berkesan lebih hidup, warna yang digunakan adalah warna yang cerah.

6) Tekstur; tekstur adalah permukaan suatu benda yang dapat dilihat dan dapa dirasakan. Pada bahan busana, sifat permukaan kain dapat pula dilihat dan dirasakan, di antaranya lembut, kasar, halus, tebal, tipis, dan tembus terang.

Prinsip desain adalah suatu cara untuk menyusun unsur-unsur, sehingga tercapai perpaduan yang memberi efek tertentu (Widarwati, 1993: 15). Adapun prinsip-prinsip desain meliputi:

1) Keselarasan; keselarasan merupakan kesatuan di antara macam-macam unsur desain, walaupun berbeda tetapi membuat tiap-tiap bagian kelihatan bersatu.

2) Proporsi (perbandingan); proporsi adalah perbandingan antara satu dan yang lain dalam satu susunan berbeda, sehingga tercapai keselarasan

3) Keseimbangan; keseimbangan adalah penyusunan unsur-unsur desain secara baik, sehingga tampak serasi pada pemakai. Keseimbangan sangat menentukan nilai artistik dari kombinasi yang dibuat. Hal itu merupakan prinsip desain yang paling banyak menuntut kepekaan perasaan.
4) Irama; irama adalah keselarasan yang baik dapat menimbulkan kesan gerak yang menyambung dari bagian satu ke bagian yang lain, sehingga dapat mengalihkan pandangan mata dari satu bagian ke bagian yang lain. Contoh: pengulangan motif, renda, peralihan ukuran besar ke kecil atau sebaliknya.

5) Pusat perhatian; dalam suatu desain busana harus ada bagian yang lebih menarik dari yang lain, sehingga disebut centre of interest. Pusat perhatian pada busana dapat diletakkan pada salah satu bagian busana, misalnya krah, lipit pantas, kerutan, dan lain-lain. Pusat perhatian hendaklah ditempatkan pada bagian yang dianggap baik dari tubuh si pemakai.

Di samping unsur dan prinsip desain ada banyak hal yang harus dikuasai dalam penerapannya, di antaranya bagaimana menggambar proposi tubuh yang benar, apa saja yang harus ditekankan dalam pembuatan gambar desain, bagaimana mewarnai gambar busana, sehingga akan tercipta desain busana yang menarik.

Menurut Kamil (1996: 9) desain busana adalah mencipta model pakaian. Yang dimaksud mencipta adalah mengeluarkan perasaan yang kuat didorong oleh emosi, sehingga menimbulkan atau membentuk sesuatu yang baru. Jadi, mencipta mode atau fashion design adalah membuat sesuatu yang baru tentang mode pakaian. Orang yang pekerjaanya mencipta mode disebut pencipta mode atau perancang mode.

Tahapan atau langkah pembuatan desain busana seperti dikemukakan oleh Widarwati (1994: 64) sebagai berikut.

1) Menetapkan sumber ide yang akan dijadikan dasar pembutan desain busana.

2) Menggambar perbandingan tubuh, posisi tubuh, sesuai model busana yang akan dibuat. Tentukan garis keseimbangan, garis pinggang, garis panggul, dan garis lutut tepat pada tempatnya.

3) Menggambar bagianbagian busana sesuai dengan ide atau gagasan.

4) Menghapus garis-garis pertolongan yang tidak diperlukan, sehingga tinggal garis desain yang diperlukan.

5) Memberi tekstur pada desain, sehingga gambar kelihatan lebih hidup dan memberikan gambaran mengenai bahan yang digunakan.

Berdasarkan pengertian di atas, desain busana adalah rancangan busana yang dibuat berdasarkan unsur dan prinsip desain, dibuat berdasarkan langkahlangkah yang benar.

Hal penting yang dijadikan pedoman dalam mendesain busana adalah sumber ide.

Sumber ide menurut Widarwati (1996: 58) adalah segala sesuatu yang menimbulkan ide seseorang untuk menciptakan suatu desain busana yang baru atau sesuatu yang dapat merangsang lahirnya suatu kreasi baru. Namun, sumber ide dapat diambil dari bagian tertentu yang dianggap paling menarik dari suatu 
benda, tidak perlu secara keseluruhan dijadikan sumber ide. Yang dapat dijadikan sumber ide yaitu :

1) Pakaian penduduk dunia, misalnya busana dari berbagai penduduk dunia (baju dari negeri China, India, Filipina, Jepang, dan seterusnya).

2) Peristiwa-peristiwa penting nasional maupun internasional (PON, SEAGAME, HUT RI, dan seterusnya).

3) Benda-benda alam, flora dan fauna (daun, bunga, binatang), lautan, gunung berapi, dan seterusnya.

4) Bentuk geometris (bentuk-bentuk bidang datar atau bangun).

Pada proses pengembangan suatu ide yang akan dituangkan dalam menciptakan karya busana hendaknya orang mengetahui detil-detil dari suatu ide yang akan dipakai. Merancang busana tidak terikat oleh syarat tertentu, hanya saja dalam pengambilan sumber ide harus jelas dan melalui langkahlangkah yang benar.

\section{Peningkatan Kreativitas Desain Busana.}

Sumber-sumber belajar nonpersonal dapat digunakan atau disediakan oleh guru untuk membantu mentransfer materi pelajaran yang dapat merangsang pikiran, perasaan serta kemampuan siswa. Sehingga, itu lebih mengefektifkan komunikasi dan interaksi belajar mengajar dalam rangka mencapai tujuan pembelajaran. Sumber belajar suatu pendekatan dirancang untuk memudahkan siswa dalam menguasai keterampilan mendesain busana. Sumber belajar memberi pengertian kepada siswa tentang luas dan keanekaragaman sumber informasi yang dimanfaatkan untuk belajar. Dengan memanfaatkan sepenuhnya segala sumber informasi sebagai sumber belajar, siswa akan dengan mudah memahami konsep tentang cara belajar, sehingga nantinya akan mengembangkan rasa percaya dir yang memungkinkan melanjutkan belajar sepanjang hidupnya.

Sumber-sumber belajar yang disiapkan dan dirancang untuk pembelajaran desain busana akan merangsang munculnya ide-ide baru dalam membuat desain busana. Sumber-sumber belajar yang dapat dipakai dalam pembelajaran desain busana adalah:

1) Sumber belajar elektronika (audiovisual, misalnya teve, video, internet, dan seterusnya)

Kelebihan sumber belajar ini adalah siswa dapat melihat berbagai tayangan tentang peragaan busana, pengetahuan tentang mode, pengetahuan tentang bahan busana, sehingga akan mendorong munculnya ide baru dari siswa dalam mendesain busana.

Dari internet (web) akan diketahui tren mode saat ini, sehingga pengetahuan siswa akan selalu berkembang dan merangsang untuk lebih kreatif dan bervariasi dalam mendesain busana. Dengan menggunakan sumber in seseorang yang belajar tentang desain busana akan mengetahui hal yang baru tentang mode busana, sehingga memacu untuk meniciptakan desain busana yang baru.

2) Media Cetak

Sumber belajar ini di antaranya majalah mode, tabloid, surat kabar, buku desain busana, pamflet, dan seterusnya. Kelebihan sumber belajar media cetak adalah informasi akan lebih jelas dan bisa dibaca berulang-ulang.

Pendapat Ginberg \& Harrison seperti dikutip Munandar (1995: 73) bahwa salah satu cara atau petunjuk yang dapat membantu dan membina kreativitas anak, yaitu mengusahakan anak dengan aneka ragam buku, majalah, surat kabar, dan bahan-bahan lain yang dapat memperkaya dan menantang kecerdasan dan kreativitasnya. Pengetahuan yang didapat dari gambargambar mode busana dan membaca informasi sekitar tren mode pada media cetak akan mempengaruhi tingkahlaku siswa dalam belajar mendesain busana. Pesan yang ditangkap melalui gambar-gambar mode akan menimbulkan fantasi yang akan mendorong kreativitas siswa untuk mengembangkan gagasan atau ide-ide, sehingga dapat menciptakan desain busana baru.

3) Kunjungan Lapangan.

Yang dimaksud sumber belajar kunjungan lapangan adalah sumber belajar dari hasil terjun lansung ke suatu tempat yang ada kaitannya dengan desain busana. Misalnya, kunjungan ke rumah mode (butik), toko busana, garmen, dan sekolah mode. Kunjungan ke lapangan dilakukan supaya siswa mendapatkan sumber belajar baru yang dapat memunculkan ide baru dalam mendesain busana. Dengan berkunjung ke rumah mode (butik), toko busana, garmen, siswa akan lebih merasakan karena dapat melihat dan mengamati secara langsung busana yang dipajang, sehingga mengetahui detil-detil busana yang ada. Dengan mengikuti studi banding ke sekolah mode, mereka akan lebih antusias, bertambah pengalaman, pengetahuan, dan siswa lebih percaya diri.

\section{Penutup}

Pembelajaran yang menggunakan sumber-sumber belajar seperti di atas adalah pembelajaran yang mengupayakan proses belajar-mengajar dibuat sekomunikatif mungkin, sehingga situasi belajar lebih menyenangkan siswa. Pembelajaran yang kreatif membantu siswa menjadi lebih berhasil jika guru memberdayakan siswa agar mereka mampu menangani dan memecahkan masalah.

Menurut hasil penelitian Widarwati dan Yuliati (2006: 54) yang berjudul "Peningkatan Kreativitas Mendesain Busana Melalui Penerapan Model Pembelajaran Resource Based Learning pada Mahasiswa Program Studi 
Pendidikan Teknik Busana", belajar dengan menggunakan sumber-sumber belajar seperti media elektronika (teve, video, internet) dan berbagai media cetak (bukubuku desain busana, majalah mode, tabloid, koran) sangat membantu meningkatkan kreativitas dalam belajar desain busana. Hal itu terlihat pada hasil desain busana salah satu mahasiswa Program Studi Pendidikan Teknik Busana.

Pada gambar 1 (dalam lampiran), dengan cara konvensional, masih ada kelemahan-kelemahan dalam pembuatan desain busana (proporsi kurang luwes, penyelesaian rambut, detil busana, teknik penyajian gambar, dan bentuk asesoris kurang sesuai). Pada gambar 2 dan 3 (dalam lampiran), dengan menggunakan media cetak dan elektronik, hasilnya sudah terjadi perubahan, desain lebih luwes, prosporsi bentuk tangan lebih luwes dan sebanding, penyelesaian bentuk rambut lebih luwes. Pemahaman materi lebih matang, sehingga menghasilkan busana yang lebih indah, lebih bervariasi, penyelesaian lebih sempurna.

Dengan menggunakan sumber-sumber belajar dari media cetak, elektronik, dan kunjungan lapangan, sering berlatih, dan berdiskusi atas tugastugas, akan dapat menambah pengetahuan dan wawasan siswa tentang desain busana, yang pada akhirnya akan dapat meningkatkan hasil belajar siswa dalam mendesain busana. Pembelajaran desain busana yang dilaksanakan dengan menggunakan berbagai sumber dapat dijadikan sebuah alternatif pembelajaran yang kreatif bagi siswa dalam belajar desain busana.

\section{Daftar Pustaka}

Amien, Moh. 1984. Belajar Mengajar yang Inovatif dengan Menggunakan Pendidikan Humanistik. Yogyakarta: IKIP Yogyakarta.

Chodijah, Wisri A Mamdy. 1982. Desain Busana. Jakarta: Depdikbud.

Hamalik, Oemar. 1994. Media Pendekatan. Jakarta: Citra Aditya Bakti.

Kamil, Sri Ardiati. 1996. Fashion Design. Jakarta: CV Baru.

Mardapi, Djemari. 1995. Pengembangan Sekolah Kejuruan dalam Menghadapi Era Perdagangan Bebas 2020. Makalah disampaikan dalam rangka Dies Natalis ke-31 IKIP Yogyakarta, 13 Mei 1995.

Munandar, Utami. 1987. Mengembangkan Bakat dan Kreativitas Anak Sekolah. Jakarta: Gramedia.

1999. Kreativitas dan Keterbakatan. Jakarta: Gramedia.

Nasution, S. 2003. Berbagai Pendekatan dalam Proses Belajar Mengajar.

Jakarta: PT Bina Aksara.

Riyanto, Arifah A. 2003. Teori Busana. Bandung: Yapenda.

Sawitri, Sicilia. 1998. Ilustrasi Mode. Yogyakarta: FT IKIP Yogyakarta.

Sujana, Nana. 1997. Teknologi Pengajaran. Bandung: Sinar Baru.

Sujana, Nana \& R Ibrahim. 1996. Perencanaan Pengajaran. Jakarta: Rineka Cipta.
Supriadi, Dedi. 1994. Kreativitas, Kebudayaan, dan Perkembangan Ilmu Pengetahuan dan Teknologi. Bandung: Alfabet.

Usman, M. Uzer. 1993. Upaya Optimalisasi Kegiatan Belajar Mengajar. Bandung: Remaja Rosda Karya.

Widarwati, Sri. 1993. Desain Busana I. Yogyakarta: FPTK IKIP Yogyakarta - 1996. Desain Busana II. Yogyakarta: FT IKIP Yogyakarta.

2006. Peningkatan Kreativitas Mendesain Busana Melalui Penerapan Model Pembelajaran Resource Based Learning pada Mahasiswa Program Studi Pendidikan Teknik Busana, Hasil Penelitian. Yogyakarta: FT UNY.

Winkel, WS. 1996. Psikologi Pengajaran. Jakarta: Gramedia.

Lampiran: Gambar Desain Pakaian
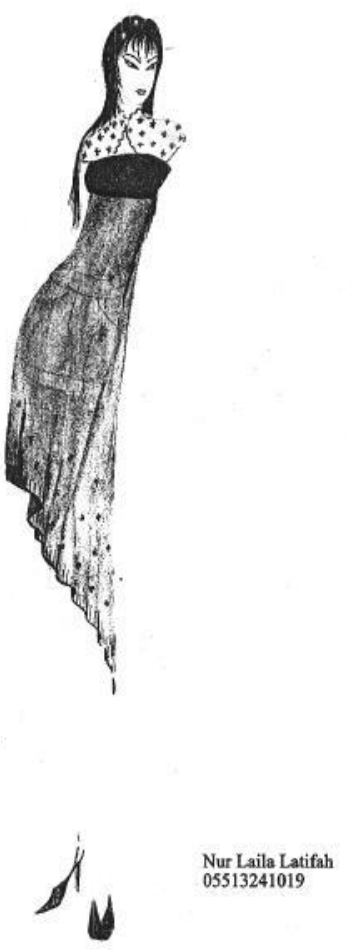

Gambar 1. Hasil Pembejaran Konvensional. 


$$
\frac{\pi}{i}
$$

